\title{
IMPLEMENTATION OF PROJECT CITIZEN MODEL BASED ON CHARACTER EDUCATION TO IMPROVE THE CRITICAL THINKING SKILLS
}

\author{
Eka Aprilya Handayani, Asti Sugiarti Sonodihardjo, Asmawati \\ Politeknik Pertanian Negeri Pangkajene Kepulauan, Indonesia \\ Jalan Poros Makassar Pare-Pare Km. 83, Mandalle, Pangkep, South Sulawesi, Indonesia \\ Corresponding Author: ekaaprilya9@gmail.com
}

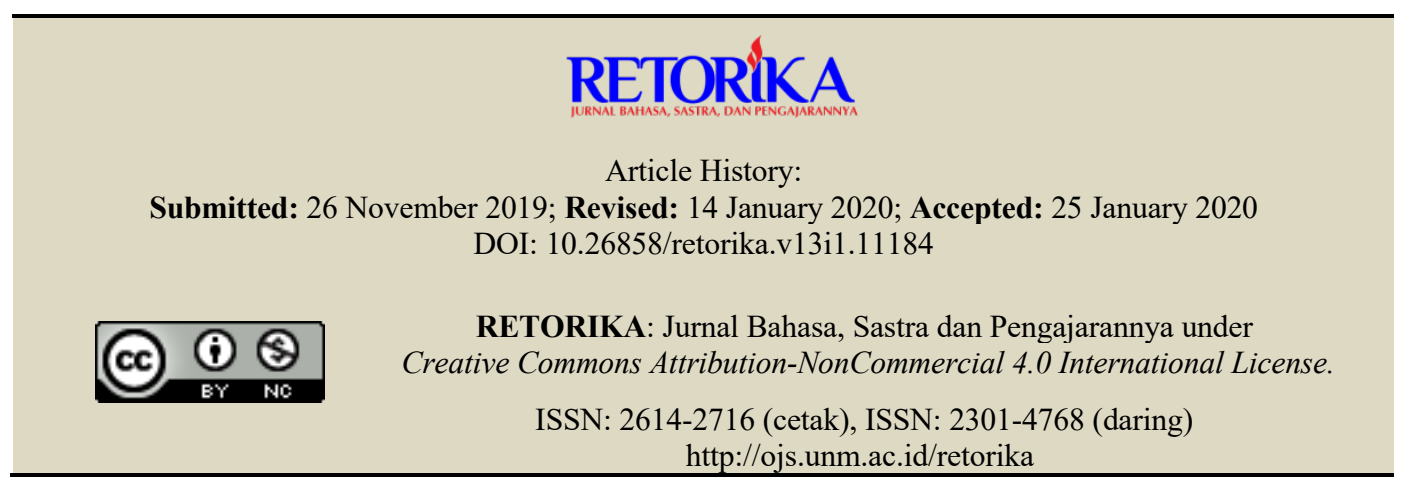

\begin{abstract}
This study aims to determine the increase in students' critical thinking skills through the implementation of a citizen education model based on character education. The method used is a Classroom Action Research (CAR) which includes planning, action, observation, and reflection. The subjects of this study were students of Politeknik Pertanian Negeri Pangkajene Kepulauan 32nd 2019 in the Agro-Industry Study Program. Data collection was performed using test and nontest techniques. The form of data analysis uses qualitative analysis. It can be concluded that the implementation of learning with the project citizen model succeeded in increasing students' critical thinking skills in MKWU learning. This is evidenced by the increase in the average percentage of critical thinking skills in both cycles. Increased students' critical thinking skills occur because the project citizen model is based on the process of involving students in identifying real problems that originate from the surrounding environment so as to stimulate the ability to reason and think reflective which is focused on deciding the things that are believed and done. In addition, indicators interact with ethics and polite language as a component of character education also increased.
\end{abstract}

Key words: project citizen, character education, critical thinking skills.

Each university must be able to produce independent and competitive competition, in accordance with the demands and global competition in the industrial era 4.0. In addition to field competencies that are in accordance with the study achievements of the Study Program, graduates' competitive advantage can also be seen in terms of soft skills, character, and gathering skills. In this case, the Compulsory General
Course (MKWU) in Higher Education is a place for character development, critical thinking skills, and student creativity.

Two of the four members of the MKWU family present at the Polytechnic are Bahasa Indonesia and Pendidikan Kewarganegaraan, in addition to Religious Education and English. Indonesian Language courses for students to be able to produce academic texts, both oral and 
written, Citizenship courses then learn so that students are able to show their identity as good Indonesian citizens by having sensitivity to national problems that arise in society.

Both MKWUs require critical thinking skills that students must have in order to successfully achieve these learning goals. Critical thinking is a sensible and reflective question that is needed to make conclusions and decide what to believe or do. (1) explain what can be done through problems or questions, analyze, clarify challenging arguments, and translate terms; (2) a basic assessment of decisions, can be done through assessing the source's credibility and evaluating the observation report; (3) issued, carried out, performed, approved, approved, approved and approved, made deduction or induction; (4) making assumptions and integrating abilities; and (5) sensitive to feelings, level of knowledge, and level of excess of others (Puspaningrum, 2017)

Critical thinking can occur when getting stimuli from the outside so that it can provide direction in thinking and working. It means not only to think intentionally, but also to examine how we and others use evidence and logic. Spliter in Komalasari (2010) argues that critical thinking skills are reasoning and reflective thinking skills that are focused on deciding things that are believed and done.

To obtain sufficient critical thinking skills, it is necessary to implement learning models that can support the achievement of these skills. Project citizen model is a teaching method or approach that uses real condition problems as a context for students to learn about critical thinking and problem solving skills, as well as to obtain essential knowledge and concepts from subject matter. Lecturers participate in building student understanding. Lecturer participation should be limited to the role of facilitators and student learning partners, for example stimulating and presenting the situation of thinking for students on the authentic problems of a material through the application of concepts and facts. Faced with learning conditions like this, students have a tendency to give meaning to problems and occurrence around them. This gives an indication of the thinking ability possessed by students.

The project citizen model can accustom students to an inquiry process that can facilitate learning, increase learning motivation and students' mindset, so that they internalize a critical mindset as well as character to fulfill student competencies.

Research on critical thinking skills and the implementation of the project citizen model have been carried out before, among others: Bulkis (2014) with the title "The Implementation of the Advance Organizer Learning Approach to Improve Critical Thinking Skills and Understanding Physics Concepts in Class VIII Students of SMP Negeri 1 Ma'rang Pangkep Regency". The results of the study indicate that critical thinking skills and understanding of physics concepts of grade VIII students of SMP Negeri 1 Ma'rang can be improved by using an advanced organizer approach.

Furthermore, Rahayu's research (2018) with the title "Application of the Project Citizen Model in Efforts to Improve Ecological Intelligence" and Luqman (2017) with the title "Application of the Project Citizen Learning Model to Enhance Students' Critical and Creative Thinking Skills". Both studies show that the application of the project citizen model can improve students' intelligence and thinking skills. This can be seen from the process improvement and evaluation results from cycle I to cycle II.

Based on previous research, it can be seen that critical thinking skills can be improved with a variety of learning models and media chosen. In addition, the project citizen model can be used to improve students' thinking skills because the model is based on the process of involving students in identifying real problems originating from the surrounding environment so as to stimulate the ability to reason and think reflective which is focused on deciding matters that are believed and done. Therefore, this research is motivated by the need to develop critical thinking skills by not ignoring character education as an academic person who has ethics through more innovative learning using the project citizen model based on character education.

\section{METHOD}

This research was conducted in the MKWU class (Bahasa Indonesia and Pendidikan Kewarganegaraan) and the environment around the campus. The subjects of this study were students of Politeknik Pertanian Negeri Pangkajene 
Kepulauan 32nd Year 2019 in the Class A Agroindustry Study Program, totaling 40 people.

This type of research is Classroom Action

Research (CAR). Classroom action research is conducted to improve and solve problems that occur in the learning process to improve the learning quality and learning achievement, in this case is to improve student learning intelligence.

The research design used was Kurt Lewin's Classroom Action Research (CAR) model which took place in several cycles. Each cycle consists of four stages, namely: planning, action, observation, and reflection. The planning stage is in the form of preparing a learning plan and making research instruments; the action phase includes the implementation of the learning process in accordance with the steps of the project citizen model; the observation stage is carried out by observing the results or effects of the actions taken by students during the learning process; and the reflection stage in the form of assessment and consideration of research results in each cycle. This research uses test and non-test techniques. The test technique is in the form of performance appraisal in the stages of implementing the project citizen model using a checklist of scores on a scale of 1-4. Based on the checklist, a recapitulation of assessment results is made to measure student learning outcomes.

Non-test techniques in the form of observation. The observation technique was carried out through observation using observation sheets of student activities during the learning process. The aspects observed were in accordance with the components of critical thinking skills with the norm of character education as follows. First, aspects of asking questions. The observation indicator on this aspect is how students focus the questions raised with the criteria of identifying or formulating questions and identifying or formulating problems. Second, the aspect of analyzing arguments. There are six indicators of observation in this aspect, namely identifying conclusions, identifying reasons stated, finding similarities and differences, finding relevant things, finding the structure of the solutions offered, and summarizing.

The third aspect observed is to consider credibility. The indicator of observation in this aspect is observing the project citizen assignments worked on by students, whether the source can be trusted or not. The fourth aspect is observing. Observations on this aspect are the project assignments of student citizens who have met the indicators report based on observations, report on the generalization of experiments, reinforce thinking, and condition a good way.

The fifth and sixth aspects are making deduction and making induction. Indicators make a deduction that is interpreting questions, while making an induction is to generalize and analyze the findings. The seventh aspect is making conclusions based on the results of deduction and induction carried out on the previous aspect. The eighth and ninth aspects are identifying assumptions and identifying terms. The indicator identifies the assumption, that is, whether the assumption supports the statement, while the indicator identifies the term, which is defining the material and making the interpretation.

The tenth aspect is deciding an action. There are four indicators of observation in this aspect, namely choosing criteria to consider solutions, formulating alternative solutions, determining things done tentatively, and considering the situation and then deciding. The eleventh and twelfth aspects are related to the implementation of character-based learning, namely interacting in accordance with ethics and using polite language. Observation on this aspect is focused on the presentation stage of the citizen project class.

\section{FINDINGS AND DISCUSSION}

\section{Findings}

In cycle I, the lecturer gives directions and learning objectives in advance in implementing the project citizen model. The description of the implementation of this model can be broken down into the following steps.

The first step in implementing the project citizen model is identifying public policy problems in society. This step consists of several activities carried out by the lecturer with students: discussing objectives, finding problems, informing what is known about problems in the community, and lecturers giving assignments about problems in the community that are considered important according to their abilities.

Students are expected to find information about the problem to be studied by: (1) interviewing parents or family, friends, neighbors, 
and others who are considered to have mastered the problem being studied; (2) through print sources such as magazines, newspapers and tabloids; (3) through electronic media such as television and the internet. All information obtained must be recorded for discussion in class at the next meeting. The aspects of critical thinking skills observed in this first step are aspects of asking questions, analyzing arguments, and considering the credibility of information sources.

The next step is to choose a problem to study classically. Before choosing a problem to be studied, students first conduct an assessment of the knowledge they already have about a problem in the community, with the following steps: (1) reviewing the problem that has been collected; (2) make democratic elections about the problem they will study by selecting one of the problems that have been written; (3) carry out further research on the problem chosen as material for gathering information. The aspects of critical thinking skills observed in this step are the ability to analyze arguments, observe, make deductions, make inductions, interact according to ethics, and use polite language when discussing.

In the previous step, each group has determined the problem to be studied. Next, the third meeting of the first cycle was carried out by the step of gathering information related to the chosen problem. Students carry out the following activities: (1) identifying sources of information; (2) review to obtain and document information; (3) gathering information. The aspects of critical thinking skills observed in this step are considering credibility, observing, and identifying terms.

The next citizen project learning activity is developing class portofolios. In this step, students have completed sufficient research to start making class portfolios, with the following steps: (1) classes are divided into 8 groups, each group consists of 5 people so that researchers more easily observe and easily identified individual abilities. Each group will be responsible for making one portfolio section; (2) the lecturer reviews the detailed tasks for the portfolio. The tasks of each portfolio group: explain the problem, review alternative policies, propose alternative policies, develop work plans; (3) the lecturer explains the specifications of the portfolio that is there is a screening section or display por- tofolio and a document section that contains a description of the project assignments.

The development of this portfolio is allocated in two meetings. All aspects of critical thinking skills emerge at this step so that they can be observed properly by researchers. An emerging aspect of critical thinking skills is deciding an action with reference to the indicator: choosing criteria to consider completion, formulating alternative solutions, determining what is done tentatively, and considering the situation then deciding. This happens because the developed portfolio must contain alternative policy studies, alternative policy proposals, and action plans that will be carried out to address the problems selected in the second step.

Student creativity is also honed at this step because the display portfolio created must contain aesthetic values with layouts arranged in such a way. In general, groups use cork material so that the display portfolio resembles a wall magazine. However, because the group was too focused on the display portfolio, the document portfolio was neglected, marked by inadequate discussion of the problem.

After the portfolio development is complete, the next learning step is to present the portfolio (show case) in front of all groups. In organizing the title case (show case), the lecturer as the organizer does the following: (1) preparation of the show case; (2) opening the show case; (3) presentation by groups that have been formed accompanied by questions and answers; (4) distraction; (5) audience response.

In this learning activity, all aspects of critical thinking skills can be observed, especially aspects based on character education, namely interacting according to ethics, and using polite language. Observations showed that three out of eight groups did not seem to master the contents of the portfolio. This is indicated by the frequency of students explaining while reading their portfolios, so students don't seem to understand the problem. This makes lecturers often have to remind students not to read portfolios when presenting.

The last step in learning cycle I is to reflect on the learning experience. In this reflection activity, students are invited to do an evaluation of what and how they learn. The purpose of reflection is to learn to avoid mistakes in the future and improve student performance. 
The summary of activities in the first cycle is initially students find it difficult and hesitant in carrying out every step of the project citizen activities. Lecturers provide direction so that students maximize their potential and develop teamwork. The researcher observes the communication that occurs in the student group and analyzes its suitability with the critical thinking component indicators. From one group, only one or two people are active and brave in opinion. In conducting discussions, there is still the role of the lecturer who directs in guiding the problem. So, the interference of lecturer is still very dominant in cycle I.

The results of observations of the first cycle were made into reflections, which were then carried out improvement plan for learning cycle II. The implementation of citizen project learning in cycle II has been according to plan. Students are getting used to the learning model that is applied and habitual critical thinking in solving problems in each learning activity, so that in cycle II the discussion can be smoother than in cycle I. Students are more active in conducting investigative activities and lecturers only have the role of providing guidance, no longer dominating student activities.

The findings that are deficient in cycle I have increased in cycle II, namely the display portfolio that aired has increased quality. One group succeeded in making innovation by using used materials in making display portfolios. The group uses used materials from eggshells and egg racks that have been discarded, then the portfolio is given the theme "eggcelent", mimicking the word "excelent" which means "great", but incorporating the word "egg", according to the material used.

The quality of the document portfolio has also improved because the discussions reviewed were adequate. In addition, in the show or show case, all groups have successfully made a good presentation and mastered the problem. The issues raised in cycle II are: increasing BPJS fees and their impact on coastal communities; increased frequency of accidents due to neglect of the use of safety equipment; prostitution in the border area of Pangkep-Barru Regency; decreased student interest in reading; addicted to gadgets and games among students; rampant legalization; cases of sexual harassment; and the phenomenon of crosshijaber.

Performance test results have increased from cycle I to II. In the first cycle, as many as 17 out of 40 students did not reach the minimum completeness score, while in the second cycle, $40(100 \%)$ students succeeded in achieving the minimum completeness score. Likewise the results of observations from cycle I to cycle II have increased. In the first cycle, the average percentage of students' critical thinking skills was $66.87 \%$, and in the second cycle $80.19 \%$. The increase in students' critical thinking skills from cycle I to cycle II was $13.32 \%$. The results of students' critical thinking skills are presented in table 1 .

Table 1. Observation Results of Critical Thinking Skills

\begin{tabular}{|c|c|c|c|}
\hline \multirow{2}{*}{ No } & \multirow{2}{*}{ Components / Indicators } & \multicolumn{2}{|c|}{ Average (\%) } \\
\hline & & Cycle I & Cycle II \\
\hline 1. & Asking questions & 65,56 & 76,04 \\
\hline 2. & Analyzing arguments & 60,80 & 78,58 \\
\hline 3. & To consider credibility & 75,55 & 87,70 \\
\hline 4. & Observing & 65,72 & 76,35 \\
\hline 5. & Making deduction & 68,42 & 75,35 \\
\hline 6. & Making induction & 60,25 & 75,20 \\
\hline 7 & Making conclusions & 62,36 & 75,20 \\
\hline 8. & Identifying assumptions & 70,23 & 80,66 \\
\hline 9. & Identifying terms & 71,23 & 88,40 \\
\hline 10. & Deciding an action & 67,87 & 81,80 \\
\hline 11 & Interacting in accordance with ethics & 65,56 & 85,30 \\
\hline & Using polite language & 68,87 & 83,45 \\
\hline & Average & 66,87 & 80,19 \\
\hline
\end{tabular}


The Table 1 shows an increase in the average percentage of critical thinking skills of each cycle. In the first cycle, the average critical thinking skills of students is $66.87 \%$. The second cycle became $80.19 \%$ or an increase of $13.32 \%$. Indicators of critical thinking skills that obtain a high percentage are identifying terms of $88.40 \%$ and considering credibility of $87.70 \%$. In addition, indicators of interacting with ethics and polite language as a component of character education also increased.

\section{Discussion}

The application of the project citizen model is an effort to direct learning activities, especially in problem solving activities. By using this model, it is expected to increase learning activities, thereby affecting the level of student activity in participating in each learning process. The application of the project citizen model technique aims to educate students to be able to analyze various dimensions of public problems, then with their capacity as "young citizens" trying to provide input to public problems in their environment. The expected outcome is the quality of an intelligent, creative, participatory, prospective, and responsible generation. A more organized implementation makes it easier for lecturers and students to follow each learning process. Learning activities run optimally if the student's response to the learning process shows a maximum percentage of activeness. Therefore, the role of the lecturer as a facilitator with the student as a learning center is very influential on the level of student activity.

Performance test results and observations of each learning meeting illustrate that the acquisition of grades and activities of students in cycle I and cycle II has increased. The acquisition of student performance test scores in the first cycle is considered sufficient because $40 \%$ of students did not achieve the minimum value, but increased significantly in the second cycle because the acquisition of student scores as a whole has reached the assessment standard. Likewise, the results of observations or observations of aspects of critical thinking skills that include 12 aspects with each indicator have increaseed from cycle I to cycle II, so this research ends in cycle II.

Based on this description, it can be seen that the project citizen model can improve stu- dents' critical thinking skills by conditioning them to identify problems, analyze arguments, gather information, conduct teamwork, and provide alternative solutions. This finding reinforces the theory that the project citizen model according to Budimansyah (2009) can provide meaningful learning experiences for students in terms of presenting ideas to others, and learning to convince them to be able to understand and accept these ideas; enhance the role of students actively in learning activities; and invites students to learn responsibly for what they have done, both in the classroom and outside the classroom in the context of implementing the learning program.

The process of implementing project citizen learning steps, specifically portfolio development and portfolio presentation (showcase) provides a meaningful learning experience for students about the importance of optimizing reasoning, thinking skills, team communication, and creativity while making students not experience the compulsion in learning because of the learning situation very fun and different from conventional models that just sit and listen. The character of students in teamwork and the process of reaching consensus is also highly developed in this process. Collaboration between lecturers as a research team in preparing learning plans and making the implementation of the learning process run optimally and enthusiasm of students in following the learning process in accordance with planned procedures and targeted goals.

An increase in the average value of critical thinking skills along with the increased ability of students to overcome a problem. Students can come up with ideas and not be afraid anymore in argumentation or opinion. Students' knowledge about problems and their solutions has begun to be wide open and has mature ideas in exploring the material. From the research results it is clear that basically students have the potential to think critically. This potential is unfortunate if it cannot be developed properly accompanied by strong character ownership. Through the application of the project citizen learning model, students can develop critical thinking skills.

The results of the study are in line with research on the application of the project citizen model that was carried out previously, namely Rahayu's research (2018) with the title "App- 
lication of the Project Citizen Model in Efforts to Enhance Ecological Intelligence" and Luqman research (2017) with the title "Application of the Project Citizen Learning Model for Improving Students' Critical and Creative Thinking Skills ". Both studies show that the application of the project citizen model can improve students' intelligence and thinking skills. Therefore, with this research and previous research, it can be seen that the application of the project citizen model can improve critical thinking skills.

\section{CONCLUSION}

Based on the results of the study, it can be concluded that the implementation of learning

\section{REFERENCES}

Budimansyah, D. (2009). Inovasi pembelajaran project citizen. Bandung: Program Studi SPS UPI.

Bulkis, T. M. \& Azis, A. (2014). Penerapan pendekatan pembelajaran advance organizer untuk meningkatkan keterampilan berpikir kritis dan pemahaman konsep fisika pada peserta didik kelas VIII SMP Negeri 1 Ma'rang Kabupaten Pangke". Jurnal Sains dan Pendidikan Fisika, 10(3), 314-323.

Komalasari. (2010). Pengaruh pembelajaran kontekstual dalam pendidikan kewarganegaraan terhadap kompetensi kewarganegaraan. Jurnal UPI Bandung, 27(1), 47-55.

Luqman. (2017). Penerapan model pembelajaran project citizen untuk meningkatkan keterampilan berpikir kritis dan kreatif siswa. Jurnal Ilmu Pendidikan, 2(1), 44-59. with the project citizen model can improve students' critical thinking skills in MKWU learning. This is evidenced by the increase in performance test results and the average percentage of critical thinking skills in both cycles. Increased students' critical thinking skills occur because the project citizen model is based on the process of involving students in identifying real problems that originate from the surrounding environment so as to stimulate the ability to reason and think reflective which is focused on deciding the things that are believed and done. In addition, indicators interact with ethics and polite language as a component of character education also increased.

Lewin, K. (2012). Classroom action research: Methods and techniques. London: Oxford University Press.

Puspaningrum, Y., Dasna I, \& Wonorahardjo, S. (2017). "Keterampilan berpikir kritis mahasiswa pendidikan kimia semester 6 materi unsur golongan 11 dan 12". Prosiding Seminar $\mathrm{Na-}$ sional Kimia dan Pendidikan Kimia IX, hlm. 132-139.

Rahayu, G. (2018) "Penerapan model project citizen dalam upaya meningkatkan kecerdasan ekologis. Jurnal Mimbar Sekolah Dasar UPI, 5(1), 31-42.

Rahmawati, I., Hidayat, A., Rahayu, S. (2016). “Analisis Keterampilan Kritis Siswa pada Ma-teri Gaya dan Penerapannya. Prosiding Semnas Pendidikan IPA Pascasarjana UM, 1, 11121119. 